\title{
Cost Effectiveness of Dietary Valine Supplementation on Broiler Ration
}

\author{
K. Selvarasu ${ }^{1 *}$, R. Amutha, S. C. Edwin and A. Natarajan \\ Department of Poultry Science, Tamil Nadu Veterinary and Animal Sciences University, \\ Veterinary College and Research Institute, Namakkal, India \\ *Corresponding author
}

\section{Keywords}

Body Weight, Broiler, Cost, Feed Consumption, Ration, Valine

\section{Article Info}

\section{Accepted:}

07 January 2021

Available Online: 10 February 2021

\section{A B S T R A C T}

An experiment was conducted in commercial broiler chicks (Vencobb) for a period of six weeks to study the dietary supplementation of valine with respect to Body weight and Cumulative feed consumption, total feed cost per bird (Rs), Total cost of production per $\mathrm{kg}$ live weight (Rs), Total income per bird (Rs), Net profit per kg live weight (Rs), Net profit per bird (Rs). These broiler chicks were wing banded, weighed and randomly allotted into five treatment groups with four replicates of ten chicks each and fed with basal diet as $\mathrm{T}_{1}$ (control), $\mathrm{T}_{2}$ (basal diet +0.04 per cent valine), $\mathrm{T}_{3}$ (basal diet +0.08 per cent valine), $\mathrm{T}_{4}$ (basal diet +0.12 per cent valine) and $\mathrm{T}_{5}$ (basal diet +0.16 per cent valine). The dietary valine supplementation of broiler diet on sixth week body weight revealed no significant difference between treatment groups. Cumulative feed consumption showed significant $(\mathrm{P}$ $<0.05$ ) difference between treatment groups at sixth weeks of age. The $\mathrm{T}_{2}$ group (basal diet +0.04 per cent valine) recorded the lowest Production cost per kg live weight(Rs 57.31) and highest Total income per bird(Rs 174.68), Net profit per kg live weight (Rs16.69) and Net profit per bird (Rs39.39). Based upon this study, it is concluded that supplementation of valine in broiler basal diet at the level of 0.04 per cent ( $T_{2}$ group) significantly increased sixth week body weight and Total income per bird, Net profit per kg live weight and Net profit per bird in a cost effective way.

\section{Introduction}

The rapid growth of broiler chicken demands high level of well balanced nutrients in the ration, especially with amino acids for marketing at an earlier age. The inclusion of different feed ingredients in broiler ration mainly depends on their nutritive value, availability and cost. A major concern of modern broiler enterprise is to reduce the feed cost for optimal return because feed constitutes approximately 70 per cent of the production cost. Amino acids are important components of all poultry diets. They are in constant turnover in the body and without proper dietary intake; deficiencies can cause detrimental effects on growth, immunity and production. These amino acids play an important role in structural and protective tissues in the body and are also important in enzyme and tissue functions (N.R.C 1994). Amino acids might also impact the muscle composition and the meat quality and more over final product stability. Most of the 
broiler feed formulation with maize and soya are limited in lysine and methionine. However, recent studies proved that threonine and valine are also important in case of fast growing broiler. The inclusion of L-valine in all vegetable maize soybean meal feeds may further reduce the production cost without altering the performance of broilers since valine has been recognized as the fourth limiting amino acid in this type of diet (Corzo et al., 2007). Hence, this research programme has been designed to assess the cost effectiveness by including graded levels of valine in broiler ration.

\section{Materials and Methods}

A biological study was conducted with two hundred sex-separated day-old, commercial broiler (Vencobb) chicks belonging to single hatch. These chicks were wing banded, weighed and randomly allotted into five treatment groups with four replicates of ten chicks each. All chicks were reared up to 6 weeks in deep litter system in open sided broiler house under standard managemental conditions throughout the experimental period. The treatment groups consisted of basal $\operatorname{diet}_{1}$ (control), $\mathrm{T}_{2}$ (basal diet +0.04 per cent valine), $T_{3}$ (basal diet +0.08 per cent valine), $\mathrm{T}_{4}$ (basal diet +0.12 per cent valine) and $\mathrm{T}_{5}$ (basal diet +0.16 per cent valine). The experimental feed was formulated according to the Vencobb standards by supplementing valine at different levels. All the diets were isocaloric and isonitrogenous. Relative economics of broilers fed diets supplemented with valine was worked out to evaluate the cost effectiveness using the prevailing market rates. The data collected on body weight and cumulative feed consumption at sixth week were subjected to statistical analysis as per the methods suggested by Snedecor and Cochran (1989). Angular transformation was applied to percentages wherever needed before carrying out statistical analysis.

\section{Results and Discussion}

The data on mean body weight (g) and cumulative feed consumption (g) of broilers at 6 weeks of age as influenced by dietary supplementation of valine are presented in Table 1.

The mean body weight at sixth week of age in broilers did not differ significantly due to dietary supplementation of valine. The highest sixth week body weight was recorded in $\mathrm{T}_{2}$ group $(2360.5 \mathrm{~g})$ followed by $\mathrm{T}_{3}(2305.5$ $\mathrm{g}), \mathrm{T}_{5}(2299.2 \mathrm{~g}), \mathrm{T}_{4}(2295.6 \mathrm{~g})$ groups and lowest in $\mathrm{T}_{1}(2185.6 \mathrm{~g})$ group.

Table.1 Body weight and Cumulative feed consumption of broilers at 6 weeks of age as influenced by dietary supplementation of valine

\begin{tabular}{|l|l|l|}
\hline Treatment groups & Body weight & $\begin{array}{l}\text { Cumulative feed } \\
\text { consumption }\end{array}$ \\
\hline $\mathbf{T}_{\mathbf{1}}$ - Basal diet $($ Control $)$ & $2185.6 \pm 29.2$ & $3663.5^{\mathrm{b}} \pm 70.4$ \\
\hline $\mathbf{T}_{\mathbf{2}}$ - Basal diet $+(\mathbf{0 . 0 4}$ per cent valine $)$ & $2360.5 \pm 49.1$ & $3692.4^{\mathrm{ab}} \pm 37.1$ \\
\hline $\mathbf{T}_{\mathbf{3}}$ - Basal diet $+(\mathbf{0 . 0 8}$ per cent valine) & $2305.5 \pm 50.0$ & $3852.1^{\mathrm{a}} \pm 23.8$ \\
\hline $\mathbf{T}_{\mathbf{4}}$ - Basal diet $+(\mathbf{0 . 1 2}$ per cent valine) & $2295.6 \pm 42.3$ & $3546.8^{\mathrm{b}} \pm 81.6$ \\
\hline $\mathbf{T}_{\mathbf{5}}$ - Basal diet $+(\mathbf{0 . 1 6}$ per cent valine $)$ & $2299.2 \pm 60.6$ & $3548.4^{\mathrm{b}} \pm 59.6$ \\
\hline
\end{tabular}

Value given in each cell is the mean of four observations

$\mathrm{a}$ and $\mathrm{b}$ Means within a column with no common superscript differ significantly $(\mathrm{P}<0.05)$ 
Table.2 Cost effectiveness of broilers reared up to 6 weeks of age as influenced by dietary supplementation of valine

\begin{tabular}{|c|c|c|c|c|c|c|c|c|c|c|c|c|}
\hline \multirow[t]{2}{*}{ Treatment groups } & \multirow{2}{*}{$\begin{array}{l}\text { Body } \\
\text { weight } \\
\text { (g) }\end{array}$} & \multicolumn{3}{|c|}{ Total feed consumed (kg) } & \multicolumn{3}{|c|}{ Cost of feed per kg (Rs) } & \multirow{2}{*}{$\begin{array}{l}\text { Total } \\
\text { feed } \\
\text { cost } \\
\text { per } \\
\text { bird } \\
\text { (Rs) }\end{array}$} & \multirow{2}{*}{$\begin{array}{c}\text { Total } \\
\text { cost of } \\
\text { product } \\
\text { ion per } \\
\text { kg live } \\
\text { weight } \\
\text { (Rs) }\end{array}$} & \multirow{2}{*}{$\begin{array}{c}\text { Total } \\
\text { incom } \\
\text { e per } \\
\text { bird } \\
\text { (Rs) }\end{array}$} & \multirow{2}{*}{$\begin{array}{c}\text { Net } \\
\text { profit } \\
\text { per kg } \\
\text { live } \\
\text { weight } \\
\text { (Rs) }\end{array}$} & \multirow{2}{*}{ 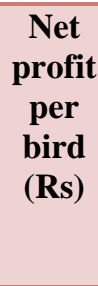 } \\
\hline & & $\begin{array}{c}\text { Pre } \\
\text { starter }\end{array}$ & Starter & Finisher & $\begin{array}{c}\text { Pre } \\
\text { starter }\end{array}$ & $\begin{array}{c}\text { Start } \\
\text { er }\end{array}$ & $\begin{array}{l}\text { Finis } \\
\text { her }\end{array}$ & & & & & \\
\hline $\mathbf{T}_{1}$-Basal diet & 2185.6 & 0.407 & 1.288 & 1.968 & 32.55 & 33.33 & 32.89 & 120.91 & 59.90 & 161.73 & 14.10 & 30.82 \\
\hline $\begin{array}{l}\mathrm{T}_{2} \text {-Basal diet }+ \\
(0.04 \text { per } \\
\text { cent valine })\end{array}$ & 2360.5 & 0.428 & 1.338 & 1.926 & 32.95 & 33.73 & 34.29 & 125.29 & 57.31 & 174.68 & 16.69 & 39.39 \\
\hline $\begin{array}{l}T_{3}-\text { Basal diet }+ \\
(0.08 \text { per cent } \\
\text { valine })\end{array}$ & 2305.5 & 0.422 & 1.356 & 2.073 & 33.35 & 34.13 & 34.69 & 132.30 & 61.72 & 170.61 & 12.28 & 28.30 \\
\hline $\begin{array}{l}T_{4} \text {-Basal diet }+ \\
(0.12 \text { per cent } \\
\text { valine) }\end{array}$ & 2295.6 & 0.374 & 1.265 & 1.908 & 33.75 & 34.53 & 35.09 & 123.25 & 58.04 & 169.87 & 15.96 & 36.63 \\
\hline $\begin{array}{l}T_{5} \text {-Basal diet }+ \\
(0.16 \text { per cent } \\
\text { valine) })\end{array}$ & 2299.2 & 0.407 & 1.281 & 1.861 & 34.15 & 34.93 & 35.49 & 124.67 & 58.57 & 170.14 & 15.43 & 35.47 \\
\hline \multicolumn{3}{|l|}{ Miscellaneous cost } & \multirow{2}{*}{\multicolumn{2}{|c|}{$\begin{array}{l}\text { Rs.10/bird } \\
\text { 74/kg. }\end{array}$}} & & & & & & & & \\
\hline Price of one kg live & eight of 1 & oiler & & & & & & & & & & \\
\hline
\end{tabular}

Fig.1 Net profit per kg live weight of broilers as influenced by dietary supplementation of valine

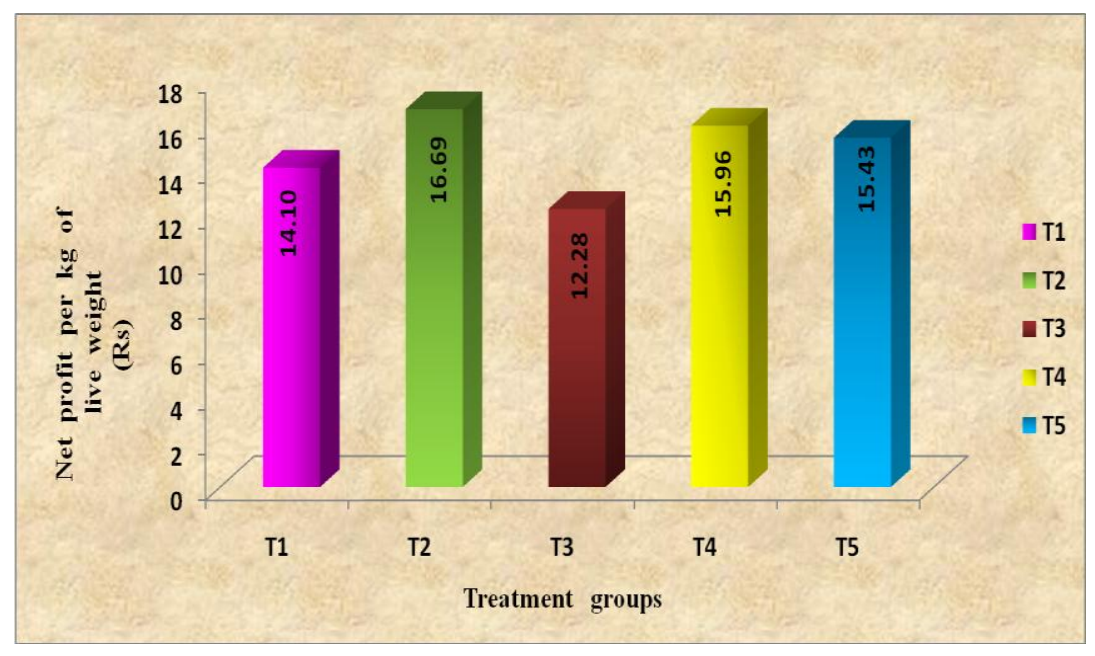

The results in this study concur with the finding of Gyurcso et al., (2011) who stated that crystalline L-valine supplementation does not affect significantly the body weight of the birds. Contrary to the findings recorded in this study Baker et al., (2002) who stated that body weight responded quadratically $(\mathrm{P}<$
0.01) to increasing doses of digestible valine. The mean cumulative feed consumption revealed significant $(\mathrm{P}<0.05)$ difference between treatment groups in sixth week of age. The mean cumulative feed consumption was significantly higher in $\mathrm{T}_{3}(3852.1 \mathrm{~g})$ group which did not differ from $\mathrm{T}_{2}(3692.4 \mathrm{~g})$ 
group. The data on cumulative feed consumption of $\mathrm{T}_{2}(3692.4 \mathrm{~g}), \mathrm{T}_{1}(3663.5 \mathrm{~g})$, $\mathrm{T}_{5}(3548.4 \mathrm{~g})$ and $\mathrm{T}_{4}(3546.8 \mathrm{~g})$ groups due to showed no significant difference among them due to dietary valine supplementation. These results are in agreement with the earlier reports of Thornton et al., (2006) and Tavernari et al., (2013) who concluded that dietary valine supplementation achieved significant effect on feed consumption at sixth week. However, Gyurcso et al., (2011) observed a non- significant effect on feed intake of broilers fed with different levels of valine in the diet.

The data on cost effectiveness of broilers reared up to 6 weeks of age as influenced by dietary supplementation of valine is presented in Table 2 and graphical representation of data is depicted in Figure 1.

The total feed cost per bird was the highest in $\mathrm{T}_{3}$ group (Rs.132.30) and the lowest in $\mathrm{T}_{1}$ group (Rs.120.91). The production cost per kg live weight was the highest in $\mathrm{T}_{3}$ group (Rs.61.72) and the lowest in $\mathrm{T}_{2}$ group (Rs.57.31). Total income per bird and net profit per bird ranges from RS.161.73 to Rs.174.68 and Rs.28.30 to Rs.39.39 respectively.

The net profit per live body weight was the highest in $\mathrm{T}_{2}$ group (Rs.16.69) and the lowest in $\mathrm{T}_{3}$ group (Rs.12.28). This is in accordance with earlier findings of Dozier et al., (2008) and Corzo et al., (2011), who reported that valine supplemented diet in broilers potentially offer a useful diet for cost reduction alternative.

Based upon this study, it is concluded that supplementation of valine in broiler basal diet at the level of 0.04 per cent ( $\mathrm{T}_{2}$ group) increased sixth week Body weight, Total income per bird, Net profit per kg live weight and Net profit per bird in a cost effective way.

\section{Acknowledgement}

The authors are thankful to the Dean, Veterinary College and Research Institute, Namakkal for providing facilities and Dr. B.V. Rao Poultry Research Foundation for providing financial grant to carry out this research project.

\section{References}

Baker, D. H, A. B. Batal, T. M. Parr, N. R. Augspurger, and Parsons, C.M (2002) Ideal ratio (Relative to lysine) of tryptophan, threonine, isoleucine, and valine for chicks during the second and third weeks post hatch. Poult. Sci., 81: 485-494.

Corzo, A., M. T. Kidd, W. A. Dozier and Vieira S.L, (2007) Marginality and needs of dietary valine for broilers fed certain all-vegetable diets. J. Appl. Poult. Res., 16: 546-554.

Corzo, A., W. A. Dozier III, L. Mejia, C. D. Zumwalt, M.T. Kidd, and Tillman, P.B (2011) Nutritional feasibility of Lvaline inclusion in commercial broiler diets. J. Appl. Poult. Res., 20: 284-290.

Dozier III W. A., M. T. Kidd and Corzo, A (2008) Dietary amino acid responses of broiler chickens. J. Appl. Poult. Res., 17: 157-167.

Gyurcso, G., T. Toth, J.Fabian and Tossenberger, J (2011). The influence of L-valine supplementation of the diets on the live weight of broiler chickens (between 1-28 days of age).Acta Agraria Kaposvariensis, 15: 71-78.

N. R. C., 1994. Nutritional requirement of poultry. National Research Council. $9^{\text {th }}$ Edn. National Academy Press, DC.

Snedecor, G. W, and Cochran, W.G (1989) Statistical methods. $8^{\text {th }}$ ed., Iowa State University Press/Ames, Iowa - 50010.

Tavernari, F. C., G. R. Lelis, R. A. Vieira, H. S. Rostagno, L. F. T. Albino and 
Oliveira Neto, A.R (2013). Valine needs in starting and growing cobb (500) broilers.Poult. Sci., 92: 151-157.

Thornton, S. A., A. Corzo, G. T. Pharr, W. A. Doizer III, D. M. Miles, and Kidd, M.T.
(2006). Valine requirements for immune and growth responses in broilers from 3 to 6 weeks of age. $B r$. Poult. Sci., 47: 190-199.

\section{How to cite this article:}

Selvarasu, K., R. Amutha, S. C. Edwin and Natarajan, A. 2021. Cost Effectiveness of Dietary Valine Supplementation on Broiler Ration. Int.J.Curr.Microbiol.App.Sci. 10(02): 701-705. doi: https://doi.org/10.20546/ijcmas.2021.1002.084 